\title{
Civil Service Training in Kazakhstan: The Implementation of New Approaches
}

\author{
Gulimzhan Suleimenova
}

Academy of Public Administration under the President of the Republic of Kazakhstan, Astana, 010000, Kazakhstan

Copyright $\bigcirc 2016$ by authors, all rights reserved. Authors agree that this article remains permanently open access under the terms of the Creative Commons Attribution License 4.0 International License

\begin{abstract}
Kazakhstan is one of the few countries in Central Asia in a historically short period of time managed to take strong positions in the international arena. However, under the conditions of rapidly changing world, the country has to face challenges driven by new requirements to civil servants professional level. Therefore, the 100 Steps Government Agenda [1] approved in 2015 establishes "The Formation of a Professional Government" as a significant priority. This requires improving approaches to training of civil servants. The purpose of the article is to examine the evolution of the civil service training system in Kazakhstan and explore recent training innovations. The article is based on the analysis of the Civil Service Law, the materials provided by the Ministry for Civil Service Affairs of the Republic of Kazakhstan (MCSA) and the findings of a survey conducted to identify training needs and effectiveness of training at the Academy of Public Administration under the President of the Republic of Kazakhstan (APA).
\end{abstract}

Keywords Civil Service, In-service Training, Retraining, Kazakhstan

\section{Introduction}

The modern world is undergoing a period of global changes and transformations. The situation in the world is becoming less predictable amid the increasing competition for resources and spheres of influence, migration growth as well as the increasing number of hotbeds of tension. These changes have given birth to many policy issues. Such priorities as providing sustainable development, the strengthening of strategic stability, counteracting terrorism and fighting against corruption have made political issues even more complex. Solving these problems requires the implementation of clear and well-defined policies, efficient operation of government agencies, high level of professionalism and huge responsibility from civil servants. Kazakhstan as one of the few countries in Central Asia which has achieved certain success in political, economic and social spheres, currently is facing new challenges in the field of public policy and administration. The Government of Kazakhstan understands that a key to successful implementation of government policy is highly qualified and motivated civil service. Well-trained civil servants are able to adequately respond to the challenges, thereby helping the government to be strong and sustainable in the modern world. Therefore, the 100 Steps Government Agenda [1] approved in 2015 establishes "The Formation of a Professional Government" as a significant priority. This requires not only elaboration of brand new approaches to formation of civil service institute but also improving approaches to civil servants training. The main objectives of training system is the development of civil servants' potential and skills necessary for meeting the present and future emerging needs in the sphere of social economic development [2]. The purpose of the article is to examine the evolution of the civil service training system in Kazakhstan and explore recent training innovations.

\section{Training Programs: International Context}

The growth of globalization and the new challenges emerging in the modern world pose greater requirements for an effective civil service training system. Many countries have special training institutions. Training programs aim at improving professional skills and qualifications of civil servants in order to increase efficiency in delivery of public services. Researchers suggest different civil service training models. International organizations recommend five steps in developing training for civil servants. Among them is a school for administrative affairs as an important step for institutionalizing civil service training [3,4]. In France, Italy, Japan and Singapore it is considered important to undergo initial training before taking office [5]. The program should be competence-based [6]. In addition, civil servants prefer practice-oriented training programs [7]. Since senior civil servants tend to be busy, a training institute should establish a flexible training scheme to accommodate their needs $[8,9$, 
10]. For example, in the Singaporean system trainees and supervisors work out a training roadmap [11]. One of the challenges is how to motivate learning. Adults may be motivated to learn something for a variety of reasons. Confidence increases motivation for learning. Learners should believe that they could achieve their goals and be successful [12]. It is necessary to correlate training with the current job profiles of civil servants [13] and their career promotion.

At the same time, the new administrative environment requires the formulation of a new paradigm of civil servants training aimed at improving their competitiveness. Thus, many countries are reviewing approaches and civil service training models. Currently, the leaders in this field are the Asian countries such as South Korea, Singapore, and Indonesia.

This study describes the civil service training system in Kazakhstan. The paper is based on the results of sociological researches and documentation analysis, i.e. the Civil Service Law and materials provided by the APA and MCSA to establish trends observed in the training system and evaluation of HR practices in government ministries and agencies.

\section{The Evolution of the Civil Service Training System}

Kazakhstan is a country which gained its independence in the early 1990s and in a historically short period of time managed to take strong positions in the international arena. However, the road to this was not an easy one. Since independence, the country has faced a large number of internal and external challenges. If neighboring with two geopolitical giants such as Russia and China, long and porous borders, disputed "territories", the lack of territorial access to the sea and remoteness from the world communications were the major external challenges, the vast territory, diverse multi-ethnic population, a relatively small volume of Kazakhstan's economy in comparison with the territory size, dispersed population were the part of internal calls. Being in such a geopolitical position and severe socio-economic situation, the country could be immersed in various social and civil conflicts during that period. Under these circumstances, the government had to implement public policies that take full account of all the challenges as well as the interests of stakeholders. However, in the first years of independence, the professional level of civil servants did not meet the challenges facing the public administration system. Public administration system has experienced growing need in competent staff. Therefore, one of the priority tasks for the independent state was to create a professional civil service.

In the early 1990s, the Government arranged a series of training for civil servants with the support of international institutions. However, the training was not sufficient to achieve a professional civil service. According to the statistics, during the first years of independence over $49.7 \%$ of civil servants from central government agencies did not attend any training courses. The majority of civil servants from local government agencies never had an opportunity to undertake training courses. It was challenging to create a professional civil service subject to (1) a lack of funding, i.e. the legislation imposed an obligation on the heads of government agencies without providing funding for training purposes; (2) a lack of human resources (HR) management skills to promote learning within an organization, identify training needs and evaluate effectiveness of training and job performance; (3) training institutions were not able to ensure training for all civil servants; and (4) prior to 1995 Kazakhstan did not have any legal framework to regulate civil service training. To address this, the Government decided to establish special training centers.

The National Institute of Interdisciplinary Training for Managers and Specialists of the Ministry of Economy of the Republic of Kazakhstan (NIITMS) was the first training center. In April 1996, it was transformed into the Civil Servants Retraining and In-service Training Institute under the Government of Kazakhstan. The National Graduate School of Public Administration under the President of Kazakhstan (NGSPA) was founded in November 1996. The NGSPA was the first school for training high-flyers. It assisted the Ecole nationaled' administration (ENA) in designing training programs, teaching methods and so on. In 1998, the Civil Servants Retraining and In-service Training Institute and the NGSPA merged into the Academy of Civil Service under the President of Kazakhstan. Its mandate expanded alongside the change of the name. The Academy of Civil Service became a center for training, research, information and analytics in the field of civil service in Kazakhstan. This included education, retraining and in-service training of civil servants.

In 2005, three central training institutions (the Academy of Civil Service, Academy of Diplomacy and Academy of the Supreme Court) merged into the Academy of Public Administration under the President of the Republic of Kazakhstan (APA). In addition, Regional Training Centers (RTC) were established in all regions of the country. These institutions have fulfilled their tasks by providing regular and high quality training of civil servants on contemporary knowledge and skills during the period of 2005-2015.

At this stage, in the framework of the 100 Steps Government Agenda civil servants training infrastructure was revised. New training centers, such as the Justice Academy and the Academy of Law Enforcement were established. These schools were established to implement professional training programs for the judiciary and law enforcement agencies. The tasks of the development and implementation of new programs corresponding to modern requirements of administrative civil servants professional development were set to APA an RTC. 


\section{Legal Framework for Civil Service Training}

In 1995, Kazakhstan adopted the Decree on Civil Service that included such concepts as a civil service, a civil servant and their rights and responsibilities. Article 12.8 established that a civil servant had a right for retraining and in-service training funded by the Government. The Government thus began setting up special civil service training institutions.

The Decree repealed in 1999. The Civil Service Act adopted in 1999 introduced new approaches to civil service human resources management (HRM). The institutional innovation of the Civil Service Act was that it established the Agency for Civil Service Affairs of the Republic of Kazakhstan. According to the Act, the Agency is responsible for coordinating activities of central and local government agencies in the sphere of HR development. HR departments in central and local government agencies are responsible for retraining and in-service training of their respective staff. In addition, Article 8.8 of the Civil Service Act of the Republic of Kazakhstan reads that a civil servant has a right for in-service training and retraining. In November 2000, the Kazakhstani Government adopted the Concept on Training for Civil Servants. After five years, Kazakhstan adopted the Decree on Training, Retraining and In-service Training Rules for Civil Servants (Decree) in order to implement the basic concept. The Decree set out further details for training of civil servants.

New the Civil Service Act, which adopted in the end of 2015, introduced new model of recruitment, promotion, motivation civil servants. Unlike previous legal laws new Act contains two new rules. At first, article 5 of the Civil Service Act of the Republic of Kazakhstan has two new additional principles relating to the training of civil servants: (a) lifelong learning and competence development, (b) practical orientation of education and training. Secondly, the Civil Service Act has special article about training civil servants. Details for training of civil servants signed in Decree on Training, Retraining and In-service Training Rules for Civil Servants, which adopted in the end 2015. At present, the Decree specifies three directions of training for civil servants: Initial training; Retraining; In-service training.

Initial training includes bachelor, graduate and post-graduate programs in universities leading to Bachelor, Master and Doctor of Public Administration degrees. The APA offers such graduate programs as Master of Public Administration, and Master of International Relations as well as post-graduate programs such as Doctor of Public Administration and Doctor of Economics.

As above mentioned there are initial training programs that take place before entering the civil service, for instance, the experience of countries such as France, Italy, Japan and Singapore. Alternatively, retraining (primary training) programs, i.e. short-term training for newly employed Corps A and Corps B civil servants are provided in Kazakhstan. Retraining programs are also available for Corps B civil servants appointed to an executive position for the first time.

According to the Decree, newly employed Corps A (senior officials) and Corps B (executives) civil servants as well as civil servants appointed to an executive position in Corps B for the first time should attend retraining programs within the first six months since their appointment. The APA and RTC provide short-term training lasting no less than 120 academic hours. Retraining programs for newly employed Corps A civil servants and Corps B civil servants appointed to an executive position for the first time may last six months from the start of the training. Retraining programs for newly employed Corps B civil servants may include distance learning.

According to the Decree, all civil servants (political staff, senior officials and executives) have an obligation to undergo in-service training (1) once every three years and (2) if a civil servant receives a low performance appraisal evaluation two times during three years. The first means that an in-service training program should aim at improving civil servants' professional skills related to performing their duties. The second provision means that an in-service training program should aim at improving civil servants' professional skills subject to performance appraisal results.

The requirements of government agencies for a training program should be agreed with the Agency. The APA, RTCs and Special Training Centers within the Ministries and private profit-making training institutions provide in-service training. Duration of in-service training varies from 24 to 80 academic hours.

\section{Civil Service Training Approaches}

The new priorities outlined in the 100 Steps Government Agenda [1] and the Strategy "Kazakhstan-2050" [14] requires a modernization of approaches to retraining and professional development of civil servants. What has caused it?

Currently in Kazakhstan along with the changes taking place in social and economic relations, there is a complicated transformation process of the role of the government itself. Government has to adjust their functions, taking into account the prevailing trends in the global world order, to participate in various inter-state and international organizations. There is a broadening and strengthening of the international component of the national economy. International companies, multinational associations (such as the Eurasian Economic Union), the WTO, to a certain extent influence the revision of the "rules of the game" in the domestic market and their activities are organically included in macroeconomic regulation. Legal regulation of the information space, environmental issues, the fight against terrorism, drug trafficking and corruption are becoming challenging problems day by day.

Along with this, there is an active process of development of civil society. However, at this point uneasy relationship established between the new civil structures and public 
authority. The Government is taking all steps to create conditions conducive to the formation of a more active civil unions and their inclusion in the scope of social processes management.

In general, the transformation of the government role requires managers owning the new management technologies, capable of managing the dynamic processes in the field of public administration, to successfully implement the new government programs. At the same time improving the efficiency of civil service should occur for the benefit of civil society development and consolidation of the state, for ensuring transparency and regulation of the activities of government agencies and civil servants, creating a positive image of the civil service in the eyes of the public. The priority of these objectives justified the need to improve the quality of public administration. The Worldwide Governance Indicators data shows that the indicators of Kazakhstan are improving over time, however it is not the best results. So, the Government Effectiveness is 54.33 out of 100, Regulatory Quality - 44,71 out of 100, Rule of Law 34,3 out of 100 , Control of Corruption - 25,96 out of 100 [15].

Particularly, sharp questions remain in increasing the responsibility of civil servants, their compliance with the highest ethical standards in planning and distribution of budgetary funds as well as the provision of public services. According to Transparency International Report 2015,
Kazakhstan occupies $123^{\text {rd }}$ position in terms prevalence of corruption in public sector. This relative improvement is in comparison with 2013 when the country ranked 140 in the rating [16].

Today, Kazakhstan is experiencing a new phase of development of a professional civil service. Institutional measures are fixed in the new Kazakh model to promote the professionalization of the civil service. Created and effectively functioning system of competitive selection of candidates for the civil service and promotion of civil servants. Besides, the following institutional innovations have been introduced as a result of the recent reforms in the civil service system: the establishment of the Senior Executive Officials Corps (Corps A), introduction of a new selection process for Corps A and Corps B (executives), introduction of a performance appraisal system of civil servants and other innovations [17]. The civil service reform requires rethinking of civil service training approaches, especially for senior executive officials and so on.

From the standpoint of the organization of training of civil servants, Kazakh training centers are guided by the directions that are defined in the regulatory Decree on Training, Retraining and In-service Training Rules for Civil Servants. The figure below indicates the current training offered to civil servants (Figure 1).

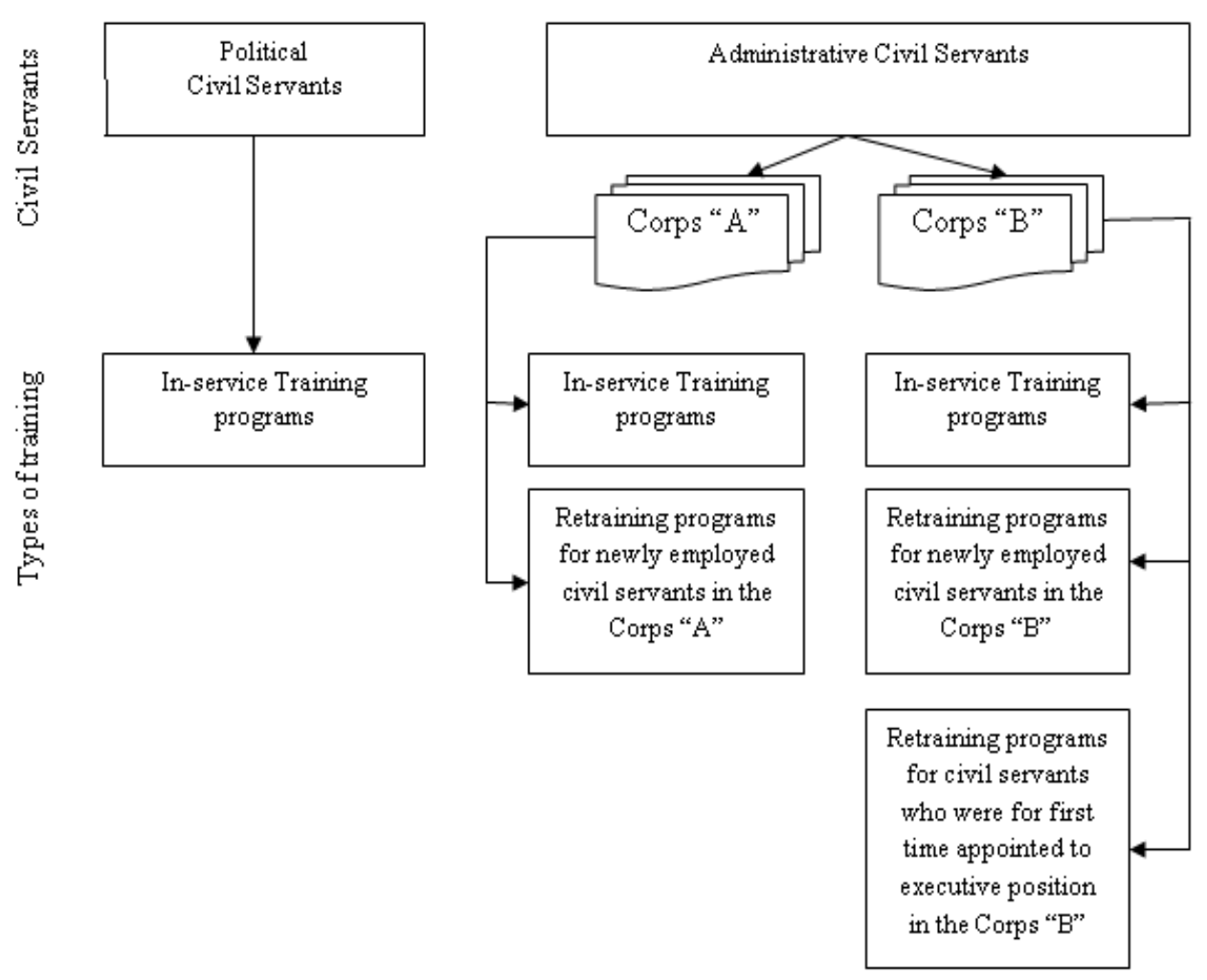

Figure 1. Types of civil service training 
It demonstrates that types of training programs vary subject to the category of civil servants. Political civil servants undergo in-service professional development and administrative civil servants attend retraining and in-service training programs. According to the Decree, the APA and RTCs provide retraining programs whereas different training institutions provide in-service training.

Every year around 200 retraining courses and more than 1,400 in-service training courses are organized in the area of civil service. The APA conducts around 30 courses from 1,400 in-service training courses, RTCs -600 whereas other training institutions conduct 800 . Since every civil servant has an obligation to upgrade his qualifications no less than once in three years, training is provided to all administrative civil servants in the country in the course of three years.

Dynamically developing events across the world are posing new challenges to governance. This in turn imposes a growing number of demands on the level of professionalism and competencies of civil servants. In these circumstances, a discussion has focused on such issues pertinent to civil service as practice-orientedness of training programs for civil servants to match their content to the needs of civil servants. The findings of the online sociological research we conducted among civil servants in 2014 and 2015 revealed the gaps in the skills and competencies that civil servants should develop. These include:

- lack of competencies in conducting research and application analysis methods $(57.2 \%$ of respondents);

- lack of competencies in formulation, implementation and evaluation of policies ( $52.1 \%$ of respondents);

- lack of competencies in development and decision-making ( $45.3 \%$ of respondents);

- lack of competencies required to perform leadership functions (42.7\%);

- lack of competencies in cooperation, communication and interaction (38.5\% of respondents);

- shortage of public speaking and presentation skills (35.8\% of respondents);

- lack of negotiations skills ( $32.5 \%$ of respondents).

Identified competencies gap indicates unreadiness of civil servants effectively perform assigned tasks in the conditions of the government role transformation. Consequently, current training practice does not fully ensure civil servants readiness to work under new conditions. Based on these findings, we have introduced the changes to the training programs for civil servants offered at the APA. The retraining programs for newly employed Corps B civil servants now include courses on Teambuilding, Communication Skills, Public Presentation Skills and Analytical Work. The retraining programs for civil servants appointed to a Corps B executive position for the first time include courses on Teambuilding, Management Solutions in the Public Sector, Protocol Rules and Public Presentation
Skills. In addition, civil servants are offered some short-term in-service training programs on Speechwriting, Presentation Skills, Leadership, International Negotiations Skills, Public Speaking, Civil Service Ethics and Image and other topics. Domestic and foreign experts with a civil service experience are invited to conduct training. The evaluation of training effectiveness has revealed that the content of the programs meets the needs of the participants. In addition, the participants have made suggestions for improving the program and methods of teaching.

The evaluation of training effectiveness places an important focus on assessment of expectations. Since 2015, we have introduced an "Assessment of Expectations" questionnaire. It is a basic questionnaire, which consists of four-five questions. We ask trainers and participants about their expectations from a training program. The introduction of this questionnaire and the subsequent discussion of the results with the participants at the end of the training have enabled us to:

(1) form an overall picture of participants' expectations (a wish list);

(2) in some cases, to adjust the training program in line with the expectations;

(3) in other cases, to adjust the expectations of participants to the purpose of training (sometimes the audience did not understand the purpose of their training and expected something quite different or had excessive demands).

In general, the introduction of the questionnaire helped us to increase the effectiveness of training programs.

Many years of experience have shown that being able to provide answers to specific questions about their activities is fundamental (very important) for government employees. Of course, only acting civil servants can provide answers to such questions. Therefore, at the APA more than $40 \%$ of classes should involve practice, for example, they should involve civil servants who have work experience in the training topic. In 2014, the share of guest lecturers in in-service training was $60.5 \%$. However, it is not easy to attract lecturers who are civil servants. On the one hand, civil servants are always busy and do not have time to deliver lectures. On the other hand, most civil servants lack of teaching skills.

It should be noted that the reform of the civil service in Kazakhstan is ongoing. The basic objective of the reform is to create a professional and compact state apparatus. In this regard, the innovation of the civil service reform of 2013 was the creation of Corps A (Senior Executive Officials). Creating Corps "A" in the Republic of Kazakhstan, as in other countries, was driven by the objective necessity of highly qualified management capable of ensuring an effective public management as well as the provision of quality public services considering public needs. It is also an essential measure for the professionalization of the civil service.

On the one hand, Corps A performing a vertical 
mediation must ensure the continuity and integrity of the state vision. On the other hand, a horizontal mediation should minimize the prevalence of bureaucratic interests in public decision-making [9].

In Kazakhstan, the number of Corps A civil servants is relatively small. Corps A consists of only about 500 civil servants, which is $0.5 \%$ of the total number of all civil servants. Meanwhile, according to the data of 2010, the share of higher grade of civil servants in the UK was $2.5 \%$, in Canada - $0.9 \%[8$, p. 3$]$.

Unlike Corps B civil servants, Corps A civil servants are contracted for four years. At the same time, Corps A civil servants are expected to lead new initiatives. It is impossible to introduce new ideas to improve the well-being of citizens without having a good professional knowledge. Therefore, training plays an important role in the activity of Corps A civil servants.

Due to the fact that Corps A has been sufficiently new phenomenon for Kazakhstan in 2013, we have intensively studied the experience of countries which have a Senior Public Service. In some countries such as India, Singapore and France civil servants cannot take up their positions unless they undergo essential training. In other countries, senior civil servants may take courses during the tenure of their position. Senior service officials in Singapore must attend at least 100 hours of training each year. The US Federal Executive Institute conducts the Senior Executive Service training after which Office of Personal Management (OPM) certifies their eligibility for entry into the Senior Executive Service [18]. Besides, the study of international experience showed the existence of different competency models in various counties. The most important competencies for senior level officials are:

(1) an ability to form a management team;

(2) a strategic vision;

(3) an ability to manage strategic change in the organization's development.

Thus, with the support of our partners - the Federal Executive Institute (USA), NHI (South Korea), ENA (France) and the EU project "Civil Service Reform and Modernization of the Government of Kazakhstan" (CSR), we have defined relevant approaches, content, forms and methods for the Corps A training. They can be considered innovative in terms of organizational innovations. As seen in Figure 1, we have identified two forms of the training for Corps A civil servants:

- in-service training;

- retraining programs for newly employed Corps A civil servants.

Taking into account specific nature of Corps A positions (for example, these would be committee chairpersons, heads of sectors, akims (governors) of districts and others) several seminars were organized. The program of target audience workshops contributed to the development of participants' management skills to the maximum of their potential through application of various teaching methods.
Since 2013, we have organized over 15 courses for 200 administrative Corps A civil servants. Foreign experts from the ENA (France), Academy of Speyer (German), Policy Advisory Group (UK) and other institutions were invited to conduct the workshops. The issues of leadership, public management, optimization of information flows, project management and auditing in government were discussed during the workshops.

In 2014, we launched training courses for staff who are newly employed in the administrative Corps A civil service. The curriculum is designed on a modular basis. It consists of a compulsory component, which includes training, case studies and elective modules. Each participant chooses three modules from the proposed modules

- Strategic and Budget Planning;

- HR in the Public Sector;

- Technologies of Political Management;

- Project Management;

- Economic Management in the Republic of Kazakhstan;

- Social Policy;

- Anti-corruption Policy.

Two modes of study are available: full-time and distance learning lasting 30-35 days. Participants attend an orientation session at the APA at the start of a course and a closing session at the end of a course. Three modules are studied remotely with the consultation support from trainers. The fourth module "Personal Effectiveness of a Senior Manager" is conducted as the training at the APA. Distance learning technologies were introduced because it was not easy for civil servants to remain away from their duties for a long time, especially in cases of leading managers. At the end of a training course, participants work in small groups on a case study and make a public presentation. In order to develop a case study based on Kazakhstani materials, six groups were formed among the APA faculty who developed case studies with the consultation support from the CSR projects. The experience of nine retraining courses shows that our approach of training is quite effective and contributes to the development of human and social capital. This is evidenced by the results of the evaluation of training effectiveness conducted through focus groups, questionnaires and face-to-face interaction. However, there are areas that we need to improve.

Currently, the most important task for the Akims of regions, who are part of Corps $\mathrm{A}$ is the development and implementation of a strategy to attract investors in individual industries. During the focus groups, they noted that they feel a great need to develop skills on providing right expertise to promote investment attractiveness of the region, creating an attractive environment for investors in the framework of the current legislation. They also noted the need to develop public speaking skills, stress management and effective communication skills. New management technologies to improve the efficiency and accountability of public authority represent a great interest for the executive secretaries and the 
chairmen of the committees. The general interest to all members of the Corps A was the issue of national security and the stability of civil society in the context of globalization. Of course, Corps A representatives' training needs is not limited to these questions, but there is a necessity to improve the quality of the training materials, introduce advanced e-learning technologies and provide opportunities for participants to choose courses that are most appropriate for them in terms of their professional and personal competencies.

\section{Perspectives on Training}

New approaches to training of civil servants introduced in the last years have shown good results. Thus, we noticed an increased interest of civil servants toward their professional development. Participants noted the importance of the following:

(1) Expansion of the introduction of case studies as a discussion of case studies enables participants to express their experiences and listen to alternatives;

(2) Implementation of a project based approach to the organization of workshops dedicated to the development of a specific governance situation;

(3) Organization of outreach workshops in the countryside to avoid disruption of participants by their workplace duties.

Summarizing the results of the evaluation of training effectiveness, we conclude that we need to develop and implement a differentiated approach to different groups of civil servants. This is because today the professional level of civil servants is very high. They come to attend a training course in order to obtain answers to specific questions related to their activities. Consequently, there is a need for a pool of professional public administration trainers from the former government employees. In this regard, we plan to study the mechanism of interaction of government agencies and training centers based on the experience of the ENA (France), NHI (South Korea), FEI (USA), and DBB Academia (Germany). For example, in the ENA acting civil servants conduct training. This approach has an effective outcome as training participants discuss real life cases.

It is recommended to implement intensive training on an individual basis for political civil servants and Corps A civil servants with the use of a tailored sequence of questions to which civil servants look for answers. This means there is a need to develop coaching in the civil service.

In addition, we need to pay attention to the process of the evaluation of training effectiveness in government agencies. HR departments should assess the changes among civil servants after they undergo training. These are their increased performance, improved quality and a reduced staff turnover. Unfortunately, at present the assessment of effectiveness of training in government agencies is not appropriately implemented.
Therefore, the growth of the civil service professionalization requires improved approaches to the training of civil servants.

\section{Acknowledgements}

I gratefully acknowledge the following people for their help in preparing this article: Mrs. Sh. Yelkeeva, Mrs. S. Mussenova, Ms. Zh. Seitkazina, Ms. G. Akanova, Ms. Z. Karamalayeva, Ms. L. Yildiz.

\section{REFERENCES}

[1] 100 concrete steps set out by President Nursultan Nazarbayev to implement the five institutional reforms. Online available from

http://www.kazembassy.nl/index.php/en/last-news/1931-100 -concrete-steps

[2] E. Chlivickas, A. Barabashev. Modernization of Civil Service Training: International Experience for Searching Rational System. Public Administration. 2013. Vol. 2. No. 38. P. 8-22. Available fromhttps://www.hse.ru/pubs/share/direct/docume nt/103154693

[3] B. Wooldridge. High Performing Schools and Institutes of Administration: The Role of Standards of Excellence. In Excellence and leadership in the Public Sector: The Role of Education and Training. New York, United Nations Department of Economic and Social Affairs/International Association of Schools and Institutes of Administration, 62-75, 2006.

[4] OECD. Country Profiles of Civil Service Training Systems. SIGMA Papers, No. 12, OECD Publishing, Paris, 1997.

[5] L. Anselmi, H. Kudo, V. Zarone. Reform of Public Service Training for Competency Management: a comparative analysis of national training institutions. Paper presented at the conference Euro-Mediterranean Dialogues on Public Management - MED 5. Available from http://www.medeu.org/documents/MED5/Papers/ANSELMI -KUDO-ZARONE.pdf

[6] A. Rosenbaum. Excellence in public administration education: Preparing the next generation of public administrators for a changing world. Excellence and leadership in the public sector: The Role of education and training, Vol. 71, No.1, 11-24, 2007.

[7] I. Maly. Experiences from Implementation of a New Civil Servants Training System in the Czech Republic - Country study. Paper presented at the NISPAcee Annual Conference Central and Eastern European Countries inside and outside the European Union: Avoiding a new divide, Vilnius, Lithuania. Available from http://www.nispa.org/files/conferences/2004/.

[8] M.Lafuente, N.Manning, J.Watkins. International Experiences with Senior Executive Service Cadres. World Bank, 2012.

[9] OECD. The Senior Civil Service in National Governments of OECD Countries. Paris, 2008. 
[10] M. Charib, J. Bourgault, D. Maltais, D. Rouillard. The Management Competencies of Senior Managers: A Look at some OECD Countries. In Excellence and leadership in the Public Sector: The Role of Education and Training. New York, United Nations Department of Economic and Social Affairs/International Association of Schools and Institutes of Administration, 25-43, 2006.

[11] S. Borins. Trends in Training Public Managers: A Report on a Commonwealth Seminar. International Public Management Journal, Vol. 2, No. 2A, 299-314, 2000.

[12] P. R. Sheal. How to Develop and Present Staff Training Courses, London: Kogan Page Ltd, 1994.

[13] R.K. Mishra. Training in Indian Civil Service: A Critical Analysis. Paper presented at the Network of Asia-Pacific Schools and Institutes of Public Administration and Governance (NAPSIPAG) Annual Conference, Beijing, PRC, $1-21,2005$.
[14] Kazakhstan $2050 \quad$ Strategy. Available from http://www.kazakhembus.com/in_the_news/kazakhstan-205 0 -strategy.

[15] World Bank. Senior Public Service: High Performing Managers of Government. Retrieved from www1.worldbank.org/publicsector/civilservice/.

[16] Worldwide Governance Indicators. Available from http://info.worldbank.org/governance/wgi/index.aspx\#home

[17] Corruption perceptions index. Available from http://www.transparency.org/research/cpi/overview

[18] Новая модель государственной службы [A new civil service model]. Available from http://kyzmet.gov.kz/ru/kategorii/novaya-model-gosudarstve nnoy-sluzhby 